Disponible en ligne : www.cahiersagricultures.fr

\title{
Innovation platforms and institutional change: the case of small-scale palm oil processing in Ghana
}

\author{
Samuel Adjei-Nsiah ${ }^{1, *}$ and Laurens Klerkx ${ }^{2}$ \\ ${ }^{1}$ International Institute of Tropical Agriculture, P.O. Box TL 06, Tamale, Ghana \\ ${ }^{2}$ Knowledge, Technology and Innovation Group, Wageningen University, Hollandseweg 1, 6706 KN Wageningen, The Netherlands
}

\begin{abstract}
Oil palm is an important industrial, livelihood and food crop in Ghana. Smallholders produce the bulk of the palm fruits and small-scale processors, mainly women, produce most of the crude palm oil. Poor practices lead to a high proportion of free fatty acids in the crude palm oil and the processors thus cannot access remunerative national and international markets. Exploratory and diagnostic studies identified the absence of rules and regulations governing processing as a major factor. An innovation platform was convened and facilitated to remove the identified institutional constraints. Based on event tracing, this paper reports a study of the effects of the innovation platform's interventions and how these were achieved. Institutional entrepreneurs are shown to play important roles: they mobilised resources such as expertise, knowledge, access to information and high-level political power to influence small-scale processors to adopt alternative practices. The institutional changes observed are shown to arise in cooperation between traditional authorities (chiefs), the district legislature and authorities at the national level, who together institutionalised the experimental actions and processes taken in the study area. The institutional elements they most affected were: rules and regulations, the legitimacy of new practices and organisational arrangements, co-generation of knowledge, material resources, and the strategic and communication skills of key actors.
\end{abstract}

Keywords: oil palm / free fatty acids / smallholders / innovation platforms

Résumé - Plateformes d'Innovation et changement institutionnel : le cas des petits producteurs d'huile de palme au Ghana. Au Ghana, l'huile de palme est un produit alimentaire et industriel important ainsi qu'une ressource monétaire indispensable aux petits producteurs, qui fournissent l'essentiel des régimes de fruits. Les petits transformateurs, des femmes pour la plupart, produisent la plus grande part de la production d'huile de palme brute. Du fait de techniques inappropriées, ces huiles contiennent une grande proportion d'acides gras libres et les transformateurs ne peuvent donc pas avoir accès aux grands marchés, nationaux et internationaux, les plus rentables. Des diagnostics préliminaires ont identifié l'absence de règles et de réglementation sur la transformation comme une contrainte majeure. Une plateforme d'innovation a été établie pour réfléchir à ces contraintes institutionnelles et agir sur elles. En se basant sur le suivi de ses travaux, cet article rapporte les effets de cette plateforme d'innovation et discute de la façon dont ils ont été obtenus. Les entrepreneurs institutionnels jouent un rôle important, par exemple ils mobilisent l'expertise, les connaissances, l'accès à l'information ainsi qu'au réseau politique de haut niveau et ont motivé les petites transformatrices à adopter des pratiques alternatives. Les changements institutionnels observés émergent de la coopération entre les autorités traditionnelles (chefs), les représentants locaux de l'État et les autorités nationales, qui, ensemble, ont institutionnalisé les actions expérimentales dans les régions étudiées. Les éléments institutionnels les plus significatifs sont : les réglementations et les règles, la légitimité des nouvelles pratiques et les arrangements organisationnels, la co-production des connaissances, les ressources matérielles, et les compétences stratégiques et de communication des acteurs clefs.

Mots clés : palmier à huile / acides gras libres / petits exploitants / plateformes d'innovation

\footnotetext{
* Corresponding author: y_nsiah@yahoo.co.uk
} 


\section{Introduction}

A growing body of research that uses a systems perspective to analyse agricultural innovation (see Klerkx et al., 2012, for a review of systems approaches to agricultural innovation) has shown that innovation is a co-evolutionary process, marked by simultaneous and interconnected changes in technology, markets and value chains, land tenure systems, and input, certification and quality control arrangements (e.g., Biggs, 2007; Adjei-Nsiah et al., 2007; Hounkonnou et al., 2012; Kilelu et al., 2013). Innovation platforms (IPs) are increasingly deployed to stimulate and support such changes (e.g., Francis et al., 2016, in press). IPs bring together key domain actors from a sector, territory, watershed, or administrative entity to negotiate the innovation process and mobilise resources in support of it (Ayele et al., 2012; Hounkonnou et al., 2012). A number of studies analyse IP management and facilitation (Ngwenya and Hagmann, 2001; Adekunle and Fatunbi, 2012; van Paassen et al., 2013) but despite some notable exceptions (Ayele et al., 2012; Nederlof and Pyburn, 2012; Kilelu et al., 2013), there is limited detailed analysis of what makes IPs effective as a tool for smallholder innovation, and especially how IPs address the institutional dimension of innovation.

The purpose of this article is to investigate how IPs act as vehicles for institutional change by drawing on literature of institutional entrepreneurship and by applying event tracing to study a multi-stakeholder platform located at Kwaebibirem District, Ghana. The study was carried out from mid-2010 to end 2013, under the Convergence of Sciences - Strengthening Innovation Systems (CoS-SIS) programme, focusing on the role of the IP in opening opportunities for innovation in smallscale crude palm oil (CPO) processing.

\section{Theoretical framework: IPs as hybrid forums for institutional entrepreneurship}

Research on innovation as a systemic and co-evolutionary process emphasizes that it is about changing the status quo in incumbent systems (Geels and Schot, 2007; Hekkert et al., 2007; Hall and Clark, 2010) that in the context of sub-Saharan Africa are often associated with institutional structures unfavourable to smallholders (Hounkonnou et al., 2012). Configurations of institutions connect and sustain what has been called the 'socio-technical regime', the whole set of technologies, practices, artefacts, behaviours, laws, regulations and norms (defined as the 'rules of the game') that keep a dominant economic system (production, trade and consumption) in a dynamically stable state (Fuenfschilling and Truffer, 2016; Holtz et al., 2008). They structure political, social and economic incentives and sanctions in human exchange (North, 1990).

Incumbent socio-technical regimes represent the status quo in terms of production, trade and consumption (Geels, 2005; Hounkonnou et al., 2012). Studies show that purposeful regime change requires active reform measures (Biggs, 2007; Farla et al., 2012), typically first developed in so-called niches where co-learning from experimentation, collective action and reconfiguration of personal and organisational relations can generate alternatives (Elzen et al., 2012). The transformative work in such niches has been called 'effective reformism'
(Roep et al., 2003; Klerkx et al., 2010), or 'anchoring of innovations' (Elzen et al., 2012). The individuals who exercise agency to bring about such changes have been conceptualised as institutional entrepreneurs (Pacheco et al., 2010; van Paassen et al., 2014). They are driven either by self-interest or more altruistic motives, by internal conviction, or by external pressures that challenge existing structures. They may work on both, informal (e.g., norms, practices, belief systems), or formal institutions (e.g., property rights, government policy, standards, etc.). The mechanisms and strategies they use often include (Pacheco et al., 2010): 1) advocacy and mobilizing collective action (building networks) to change power structures, 2) changing prevalent framings of problems and solutions, or 3) 'bending' existing institutions towards new uses (referred to as 'institutional bricolage'), for example, by building on positive deviance (Biggs, 2007). Research on the collective efforts of institutional entrepreneurs connects with studies of IPs (Kilelu et al., 2013; Ayele et al., 2012) and innovation champions (Klerkx et al., 2013) as enablers of purposeful change. Actors pursuing innovation goals create new relationships through which to mobilise material, power and financial resources (Klerkx et al., 2010). IPs can be seen as 'hybrid forums' positioned between niches and regimes (Elzen et al., 2012). Their members engage in niche activity but at the same time are connected to the incumbent socio-technical regime.

However, IPs are not a magic bullet that can solve all smallholder development problems. While they try to change the power structures that keep the incumbent system 'lockedin' and unfavourable to smallholders, IP members themselves are often part of the incumbent socio-technical regime and their diverse reasons for participation may lead to heightened conflict rather than reduction of tensions along a value chain. The skills of negotiation and facilitation of power differences are necessary but might not be available to an IP (e.g., Leeuwis, 2000). Further, a funding agency might have difficulty accepting that how IPs' actions will work out is not predictable and can have unintended consequences.

\section{The case: Ghana's oil palm domain}

Oil palm is an important crop in the economy of Ghana. Parts are used as fodder, roofing material, and wine; the mesocarp and kernel are the main sources of cooking oil and major ingredients in cosmetics. Industrial by-products from processing the kernel include activated carbon and pozolana cement, and kernel cake used as a poultry feed supplement. Ghana's demand for crude palm oil (CPO) is about 250,000 MT (MPOC, 2009) but the country produces only 233,000 MT. Female small-scale processors produce most of the CPO output (Osei-Amponsah et al., 2014). Their practice of storing palm fruits for between two and four weeks before processing leads to CPO with a high free fatty acid (FFA) content. This is not utilised by the refining industry because removal of FFAs incurs high oil losses and costs (Gibon et al., 2007). As a result, the country imports large quantities of CPO for industrial production of refined cooking oil, high value cosmetics and luxury soaps. Small-scale processors mostly sell to local markets and often find it difficult to make sufficient sales especially during peak fruit production from February to May. 
Activity

\begin{tabular}{|l|}
\hline $\begin{array}{l}\text { Cutting of fresh fruit } \\
\text { bunches }\end{array}$ \\
\hline
\end{tabular}

Storage of fruit bunches

Loosening and
storage of fruits

Sterilization of fruits

Digestion of fruits

Pressing of oil from digested fruits

Clarification of oil
Purpose

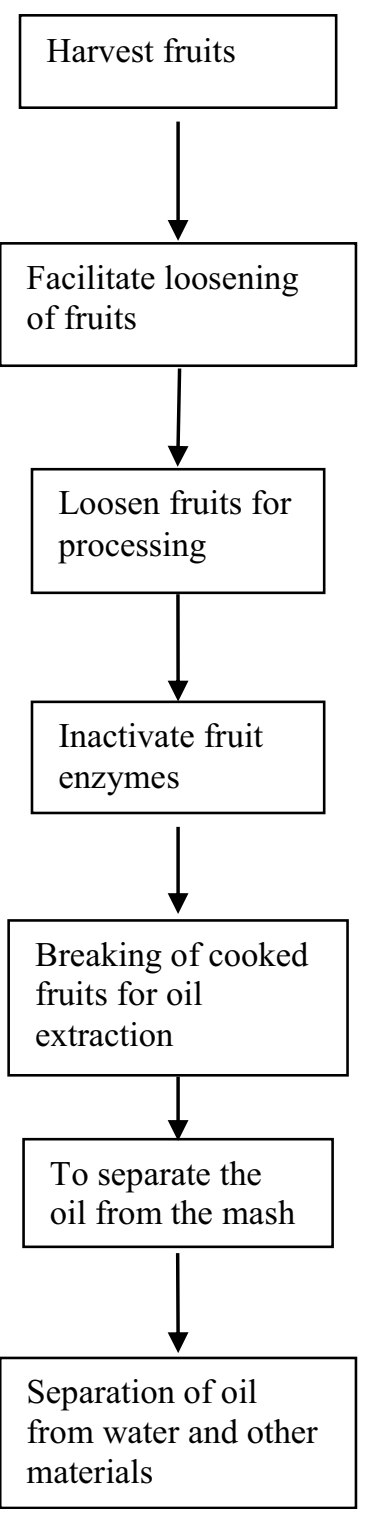

Technology/actor

Manual with axe or cutlass by farmers

On bare ground
Hand picking of fruits and drying of fruits on bare ground by women

Cooking by women using metal drums

Mechanized digesters operated by men

Partially mechanized using cage screw press operated by men

Boiling oil in drums by women

Fig. 1. Steps in palm fruit processing.

Fig. 1. Étapes de l'élaboration de l'huile de palme.

This artisanal processing sector is characterized by absence of rules and policies governing operators' practices. In addition to the problem of the high FFA content, the use of old lorry tyres as cheap fuel for fruit boiling affects CPO quality and human and environmental health. Figure 1 sketches the steps involved in extracting CPO by small-scale processors. Infrastructure is inadequate and efficient processing equipment is lacking, further competitiveness in remunerative industrial and international markets. Artisanal processors have a potential to meet Ghana's industrial and household needs in so far as they procure the bulk of the palm fruits produced in Ghana, yet they receive little government support in terms of training, access to credit and efficient equipment. The government's oil palm sector policy focuses largely on out-grower schemes attached to large-scale processing mills. However, in practice out-growers often send fruits meant for the mills to the small-scale processors.

\section{The oil palm IP}

The oil palm IP, established in July 2010 under the CoS-SIS Programme, opened a niche for institutional experimentation and for creating tested options for reforming the regime. Its eight initial members (five men, three women) were identified through stakeholder analysis carried out jointly by the facilitator (the senior author) and other stakeholders in the CPO industry. They were a smallholder farmer, an artisanal processor, a CPO miller, a representative of the Ministry of Food and Agriculture (MoFA), two from the Ghana Regional Appropriate Technology and Industrial Services (GRATIS) and one each from the Export Promotion Authority (GEPA), and the Ghana Standards Authority (GSA). This mix of local and nationally prominent actors constituted the IP as a hybrid forum operating between niche and regime. Its local base is 
Kwaebibirem District, about $120 \mathrm{~km}$ north-west of Accra, which produces the bulk of Ghana's CPO. It has a population of about 193,000 comprising some 150 villages (2010 Census). Agriculture employs about $77 \%$ of the work force and artisanal $\mathrm{CPO}$ processing is the main economic activity, employing particularly women (Osei-Amponsah et al., 2012).

Following an exploratory study (Adjei-Nsiah et al., 2012) and a diagnostic study (Osei-Amponsah et al., 2012), the initial institutional constraint identified by the IP was the absence of rules and regulations governing the practices of small-scale processors. The challenges defined by IP members were (i) what could be changed to enable artisanal processors to improve the quality of their CPO and (ii) how could they be helped to access export markets for high quality CPO. In response to these constraints, technological innovations (exploring alternative fuels for boiling oil palm fruits) and institutional innovations (developing different market channels and complying with higher production standards) were proposed. While the proposed technical and institutional innovations are not new or radical in the absolute sense, for the smallholder context they can be considered innovative as they change the existing situation and propose new ways of operating smallholder agricultural systems and value chains to benefit the smallholders (in line with Hounkonnou et al., 2012; Kilelu et al., 2013). Furthermore, the proposed innovations may at first sight be positive for smallholders but could have negative (unintended) side-effects in the long run (Wigboldus et al., 2016).

\section{Research methods}

Two main approaches were applied: action researching, comprising iterative cycles of planning, executing and learning from a series of multi-actor inquiries, institutional experiments, and $\mathrm{PhD}$ studies, and event analysis that involved documenting in real time the actions of IP members and the changes that could be analysed to emanate from these actions, a form of Theory-Guided Process Enquiry (for details see Kilelu et al., 2013; Jiggins et al., 2016a, 2016b). Two causal hypotheses were formulated for the analysis: (1) that the events were caused by actions of the IP and (2) that they were caused by exertion of power by the IP and/or other actors.

As the IP began to function, information on key events in the domain, the activities and decisions of the platform, the facilitator's comments on these and their immediate effects, were documented, then reported and analysed at periodic workshops that brought together the COS-SIS programme's Research Associate (RA) facilitators from the three countries involved (Benin, Mali, Ghana), national coordinators and an RA support team (so-called RA workshops). A narrative (i.e. a brief but rich description) about the IP and its context was written by the facilitator for each four-months period, complemented by narrative reports by the National Programme and Regional Coordinators concerning events in the domain as a whole, and in the national or international context, and the actions taken by themselves and by members of the national Programme Management Team. In addition, a facilitation diary was maintained throughout, noting how the facilitator interacted with IP members and supported their work. During the RA workshops all these data were examined against the two causal hypotheses for their explanatory power.

\section{Findings and analysis}

At the first meeting of the IP (23 July 2010, Legon) the members decided the institutional constraints they wanted to tackle, established their baseline understanding of the regime factors involved, and analysed in-depth the identified constraints as well as the interventions that might modify or remove them. The constraints were then prioritised by the members, who then discussed what might be required to bring about the desired changes, and identified activities, by whom, to accomplish these. Such analyses were periodically repeated throughout the study period to capture the evolution of the IP's understanding of the causal interactions between institutional constraints and opportunities for innovation. The facilitator also began sketching the structure of the linkages among platform members and key actors in other organisations in the domain so as to get a view of how the regime intersected with the niche. These actor linkage diagrams were periodically updated to capture changes in linkage structures as the tasks, competencies and functions of the IP matured in response to both the internal dynamics among members and the external influences emanating from the context (Fig. 2A, B, C).

In early 2011, this analysis showed that producers, processors and millers at the District level were linked by virtue of their membership in the Kwaebibirem Palm Millers Association (KBDA). In addition, the farmer member of the IP had close links with the Director of MoFA but none of the other members from the key public sector organisations even knew each other (Fig. 2A). The links that evolved subsequently are presented in a later section. Here we focus on the rules and regulations governing the practices of artisanal processors. Once these had been changed to allow and support their entry into remunerative markets for good quality $\mathrm{CPO}$, we also examine how the processors could be linked to export entrepreneurs and how processors could be organised into groups to facilitate acquisition of equipment for improving productivity.

\subsection{Rules governing processing practices}

We first present how the IP tackled the use of lorry tyres as fuel for boiling palm fruits (with the aim of discontinuing their use and come up with alternative fuels). Initially the IP had no information on who was involved and why, or on the adverse consequences of using tyres on CPO quality and processors' health. It tasked IP members from regulatory organisations with relevant expertise (the GSA and the EPA - Environmental Protection Agency) to study these issues and report back, so that the IP could share the information with key policy and value chain actors. On the basis of data supplied by these agencies, they found that tyre use was universal because tyres were cheap, readily available, and could be left to burn unattended all night while the fruits were boiled, but that the practice indeed had significant harmful environmental and human health effects.

After discussion of this information, the IP delegated three members (the processor and miller, who were also KBDA members, and the District Director of Agriculture (DDA) to share the findings with the Presiding Member of the KBDA. Convinced by what he heard, he invited the IP to give a presentation to a small 


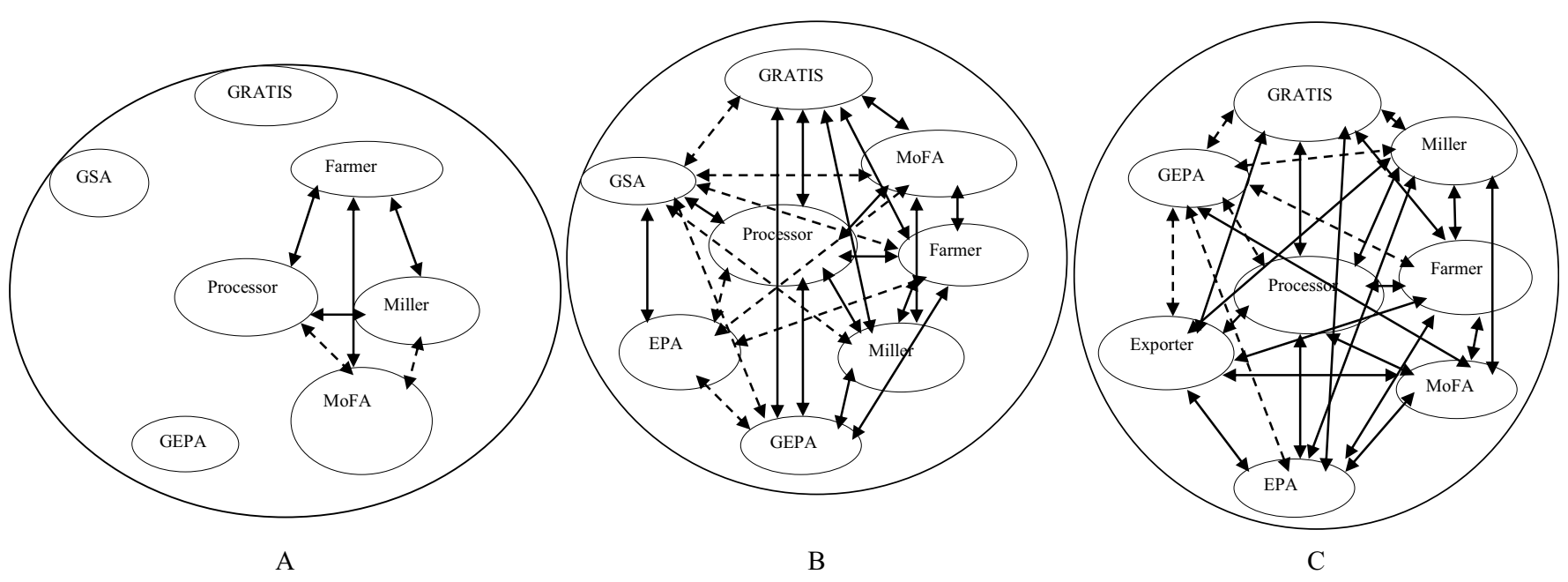

Fig. 2. IP actor linkages at three points in time: (A) 20 July 2010; (B) 25 February 2011; (C) 30 September 2012. Dashed lines represent a weak link. GRATIS: Ghana Appropriate Technology and Industrial Services; GSA: Ghana Standard Authority; GEPA: Ghana Export Promotion Authority; MoFA: Ministry of Food and Agriculture; EPA: Environmental Protection Agency (source: TGPI data and actor linkage analyses). Fig. 2. Liens entre les acteurs de la plateforme d'innovation à trois moments : (A) 20 Juillet 2010; (B) 25 Février 2011; (C) 30 Septembre 2012. Les lignes pointillées représentent un lien faible. GRATIS : Ghana Appropriate Technology and Industrial Services ; GSA : Ghana Standard Authority ; GEPA : Ghana Export Promotion Authority ; MoFA : Ministry of Food and Agriculture ; EPA : Environmental Protection Agency (source: TGPI data and actor linkage analyses).

group of KBDA executives, and subsequently to the full Assembly. After further discussion the Assembly in principle agreed to pass by-laws to ban the use of tyres and force mills to relocate to the outskirts of communities. It asked the IP to help explain the need for such rules to local people. The IP first organised a meeting with the Kwaebibirem Millers' Association, and then meetings with mill owners, mill workers, farmers, processors and chiefs within the major processing communities in the District, to share the information with them. In one village, Subi, which is home to about 16 mills, the community agreed enthusiastically with the need for change since people there were already concerned about the pollution and its effects on health. Its chief immediately imposed a ban on the use of the lorry tyres, as well as a fine of fifty Ghana Cedis (about $12 €$ ) for using them. However, most processors at first were unwilling to stop using tyres due to the difficulty of finding an equally cheap and readily available substitute. An IP member, a processor herself, suggested fibre cake and empty fruit bunches, the by-products of processing, as an alternative. A few other processors tried this option and discovered that their fuel costs were reduced by as much as $50 \%$. Thus a waste product was transformed into a resource and potential income generator, while eliminating harmful effluent. The KBDA then felt confident to enact a by-law to ban the use of the tyres throughout the district. The IP later identified the following contributions of the IP to this outcome: re-framing of the problem, assembling data, experimentation and learning from collective action, information-sharing and advocacy, development of alternatives, lobbying.

\subsection{Linking artisanal processors to remunerative markets}

Change in processing practices (especially reducing the storage time of fruits to lower the FFA content, which in turn reduces the amount of $\mathrm{CPO}$ that can be extracted (OseiAmponsah et al., 2014) is relevant for processors only if they can access remunerative markets for high quality CPO. In a separate field experiment (Osei-Amponsah et al., 2014) the women demonstrated that they could improve the quality of their CPO. The IP member from the GEPA established links between the processors to a number of export entrepreneurs. One subsequently became a member of the IP and helped the IP to mobilise resources to send CPO samples for laboratory analysis in Europe. As their understanding of the export potential grew, the processors began negotiating with another exporter who expressed strong interest in investing in the sector but a deal did not materialise because the parties could not agree on a price. The negotiations took place when $\mathrm{CPO}$ was scarce on the local market and the women could find a ready domestic market. However, they learned that it was the high cost of artisanal processing, resulting from the use of obsolete and inefficient equipment that reduced their product's competitiveness in export markets. The artisanal processors at this stage found they could benefit from producing good quality $\mathrm{CPO}$ only by accessing limited niche markets, such as Africans living overseas, local super markets and educational institutions, which would mean upgrading their production standards.

\subsubsection{Organisation of smallholders into groups}

To help improve the competitiveness of the artisanal sector the IP next decided to organise the processors into structured groups and to assist them to obtain grants to upgrade their equipment to meet standards in niche markets. Subsequently, the member from the GEPA arranged funding from his organisation for training courses for millers and about 300 processors in five $\mathrm{CPO}$ processing communities in Kwaebibirem District on group formation and management. 
The participants took the lead in organising the groups and through 2014 were receiving training to prepare them to solicit and manage equipment grants.

\subsection{Changing linkages and IP composition}

The linkages among IP members and between them and others changed over time (Fig. 2A, B, C). Initially the IP did not, for example, include an EPA representative although the IP in its first year of operations identified environmental issues as a priority problem in small-scale CPO processing. It was only in February 2011, when the facilitator approached the Executive Director of EPA that a CPO expert was assigned to join the IP. We have already seen that the IP, once the processors had demonstrated that they could improve their CPO quality, decided in May 2012 to invite an exporter to become a member. Meanwhile, the GSA member, who had earlier played a major role by carrying out the study of the effects of local processing practices on the environment and human health, showed less interest in the activities of the IP as it moved to consider market access. At the start of the IP, the relationships among the organisations represented in the IP were sporadic and loose. These only became stronger once members began to understand the contributions each of their organizations could make to support each other's goals with respect to the development of the oil palm domain.

\subsection{Institutional entrepreneurs}

Pacheco et al. (2010) identify various mechanisms and strategies institutional entrepreneurs' use, including advocacy, networking, mobilising collective actions to change power structures and prevalent framings of problems and solutions, and sometimes "bending" existing institutions towards new uses. The RA's and IP's records show that five persons played major entrepreneurial roles in championing the activities of the platform at different points in time.

\subsubsection{The Presiding Member (PM) of the Kwaebibirem District Assembly}

Although he was not a member of the IP, he used his skills and influence to organize meetings between IP members and the executives of KBDA and later also the General Assembly. In this way, he provided the IP with access to local policy makers, brokered information sharing, promoted cooperation between the District Assembly and the IP, and supported their collective actions in framing a new regulatory framework for the small-scale CPO processing industry. The PM was motivated to champion the IP's cause because of a passion for modernizing the small-scale CPO processing industry, thereby demonstrating the Assembly's and his own competence and concern for the public interest

\subsubsection{The Director of Agriculture in Kwaebibirem District (DDA)}

The Director of Agriculture in Kwaebibirem District (DDA) assisted both the IP and women processors to overcome bureaucratic barriers by mobilising the District administration and legislature as well as the Traditional Authorities (Chiefs) to advance the cause of the IP. He identified the PM as a potential champion. He lobbied for adoption throughout the District of the alternative processing practices developed through the IP, and was responsible for sustaining stakeholders' interest in strengthening the sector as a whole, though recognising that their stakes were different.

\subsubsection{The representative of the processors on the IP}

The representative of the processors on the IP, here identified as ' $\mathrm{P}$ '. She encouraged and assisted activities to find, test, and assess (technically and economically) a source of fuel that could be a viable alternative to lorry tyres. She supported and promoted the new technological opportunities that opened up through advocacy, lobbying the legislature and Chiefs, and analysed the economics of differences sources of fuel. She actively engaged in framing the alternative fuel as a viable option so as to make it appealing to the widest possible audience.

The DDA and P had been identified during the initial stakeholder analysis and their entrepreneurial skills were a major reason for inviting them to join the IP. They were motivated to join and to remain because they saw the IP as a vehicle for advancing their own ambitions to develop the opportunities for the small-scale sector that had been neglected by researchers and policy makers. $\mathrm{P}$ was especially motivated by the readiness of IP members to value her contribution as a female entrepreneur, and give her an equal chance to speak and play an advocacy role.

\subsubsection{The representative of the GEPA on the IP}

He contributed information, material and financial resources from his agency, linked processors to exporters, and helped organise the processors into groups. He is driven by the opportunity opened by the IP to export Ghanaian CPO. His commitment is notable given the focus of Ghana's oil palm sector development policy on large-scale (out-grower) plantations and processing mills, and the active discouragement of small-scale processers who were seen as unable to build a modern industry although they captured the bulk of the country's smallholder palm fruit harvest.

\subsubsection{The doctoral student employed under the CoS-SIS Programme}

She was responsible for the diagnostic studies that fed into the initial work of the IP, carried out field experiments with groups of women processors into their practices and the impact on CPO quality, and arranged for the quality of CPO from a range of fruit storage and processing options to be laboratory tested. She established that artisanal processors actually are able to manipulate their $\mathrm{CPO}$ quality to satisfy international criteria by adapting the storage periods of fresh palm fruit and by switching to alternative fuels. She showed that in the absence of access to higher price markets, the women preferred to produce lower quality $\mathrm{CPO}$ because longer storage periods allowed them to extract a larger proportion of oil (with high FFA content) to supply the local market (Osei-Amponsah et al., 2014). She worked closely with the facilitator and played a 
major role in linking the platform to researchers in the Oil Palm Research Institute (OPRI), which had hitherto neglected artisanal processing. As a woman she was indispensable in networking with the local processors.

\subsubsection{The IP's facilitator}

He was engaged by the CoS-SIS programme for the purpose of carrying out exploratory studies (Adjei-Nsiah et al., 2013), analysing actor networks, convening and facilitating the platform and carrying out relevant event analyses. In addition he played an indispensable role by coordinating and networking among the various actors to ensure their timely and appropriate contributions. If IPs are to become an effective instrument for the kind of institutional changes that can create realistic opportunities for smallholder farm innovation, as described in the case study reported here, there must be recognition among donors, governments and development administrators of the need to fund facilitation of IPs and the exploratory and diagnostic research that supports their activities

\section{Discussion and conclusions}

This case study explores how an IP modified the institutional regime so as to enable smallholder innovation. The findings support the propositions of the CoS-SIS Programme that the institutional contexts experienced by smallholders in subSaharan Africa is a major impediment to them becoming more productive, and that IPs actually can foment institutional change (Hounkonnou et al., 2012). However, a few additional observations are in order. In the first place, the research that supported the IPs work was only partly of a social science or specifically institutional nature. The (natural science) experiments with the women to improve CPO quality, as well as the scientific analysis of the toxicity of tyre smoke played a major role by creating new knowledge and a sense of common purpose among key actors. Furthermore, the institutional experimentation only had an impact in the villages in the district directly involved, and further scaling-up and scaling-out of the institutional innovation was not yet witnessed, despite the platform having wider domain representatives as members. This implies that while the platform can create enabling conditions which have the potential to influence change elsewhere (Kilelu et al., 2013), platform impacts cannot be directly extrapolated to another locality such as another district. This points to the importance to think more strategically about which scales in agricultural systems and value chains need to be engaged with by innovation platform, and hence which types of members need to be recruited (Hermans et al., 2016).

Secondly, in the course of implementation, the oil palm IP became quite independent of COS-SIS in terms of choosing its priorities and mobilising resources. The programme had indicated that CPO quality should be the priority entry point for the IP's work, based on the diagnostic study. However, the IP chose to focus first on the use of lorry tyres, causing the programme's Mid-Term Review in 2011 to conclude that the IP had little impact potential. The IP skilfully followed its initial discoveries by actions that led to significant quality improvements, modernisation and re-organisation of the sector, and development of its export potential. However, while though to make positive changes, there may also be unintended side effects (Wigboldus et al., 2016), which could not yet be observed within the timeframe of the research, but this would need to be a point an IP reflects on.

A third point is that not all domain actors can be assumed to be pleased by innovation in the sector. The large mills and plantations play important roles in the political-economy. They dislike the fact that, because artisanal processors successfully compete for the fresh palm fruits produced by smallholder farmers, the large mills work below capacity. As a result, for a long time Government policy has favoured the large-scale industry. The IP took care to develop its own expertise, evidence, and networks of influence before it engaged with high-level government figures. The careful exploratory analysis of the domain (Adjei-Nsiah et al., 2012), stakeholder analysis, and composition of IP membership on the basis of individual's enthusiasm to explore what changes were needed and possible, proved to be important in achieving the outcomes documented. In relation to this point, the case study also underlines the importance of constituting IPs as hybrid forums (Elzen et al., 2012). The IP can be seen as a space in between a niche that provides space to experiment with institutional and socio-technical alternatives and the regime, as the case study shows the importance of engaging from the start with actors positioned in the prevalent institutional regime so that colearning can occur, new information can become embedded in regime thinking, and networks of influence. However, an IP cannot be immune from larger political concerns and power games, as incumbent players may also enact counter strategies (Smink et al., 2015), and the innovation platforms themselves are the scene of power struggles (Cullen et al., 2014).

The final point we want to make concerns the institutional entrepreneurs. We show that institutional entrepreneurs are brokering, lobbying, framing, networking and fomenting concerted action with the explicit purpose of changing the rules of the game. Using an institutional entrepreneur perspective to analyse innovation platforms can be helpful in identifying what types of actors should be present on the innovation platform, to make use of their change agency. However, since our analysis has tentatively engaged with the concept of institutional entrepreneurs for this case study, some relevant future questions need to be addressed. How can we identify institutional entrepreneurs outside the platform (from within or outside the incumbent regime) and how can they be enrolled on the platform? How can we balance the informal emergence of institutional entrepreneurs and the appointment of institutional entrepreneurs? How do we ensure that their active roles are not to the detriment of input from other actors on the innovation platform who are not institutional entrepreneurs? We still know far too little about institutional entrepreneurs, innovation champions and brokers in the context of African agricultural change (Klerkx et al., 2013) their roles and effects, and the limits to what they might achieve, which indicates that further research on this topic is needed.

Acknowledgements. This work was carried out within the framework and with the support of the Convergence of Sciences - Strengthening Innovation Systems (CoS-SIS) programme funded by the Directorate General of the Dutch Ministry of Foreign Affairs (DGIS/BUZA). 


\section{References}

Adekunle AA, Fatunbi AO. 2012. Approaches for setting-up multistakeholder platforms for agricultural research and development. World Applied Sc J 16(7): 981-988.

Adjei-Nsiah S, Leeuwis C, Sakyi-Dawson O, Giller KE, Kuyper TW. 2007. Exploring diversity for orienting inter-disciplinary research on cropping systems managements in Wenchi-Ghana: the significance of time horizons. Int J Agric Sust 5: 176-195.

Adjei-Nsiah S, Sakyi-Dawson O, Kuyper TW. 2012. Exploring opportunities for enhancing innovation in Agriculture: The case of oil palm production in Ghana. J Agric Sc 4(10): 212-223.

Adjei-Nsiah S, Adu-Acheampong R, Debrah K, Dembele F, Lassine S, Ouologuem B, et al. 2013. Defying "the pervasive bias" against the African smallholders: Identifying entry points for institutional change. Dev Practice 23(7): 843-856.

Ayele S, Duncan A, Larbi A, Khanh TT. 2012. Enhancing innovation in livestock value chains through networks: Lessons from fodder innovation case studies in developing countries. Sc Public Policy 39 (3): 333-346.

Biggs S. 2007. Building on the positive: an actor innovation approach to finding and promoting pro-poor institutional and technical innovations. Int J Agric Resources Governance Ecology 6(2): 144-164.

Cullen, B, Tucker, J, Snyder K, Lema Z, Duncan A. 2014. An analysis of power dynamics within innovation platforms for natural resource management. Innovation and Development 4: 259-275.

Elzen B, Van Mierlo BC, Leeuwis C. 2012. Anchoring innovations: assessing Dutch efforts to harvest energy from glasshouses. Envir Innovation Societal Transition 5: 1-8.

Farla JCM, Markard J, Raven R.Coenen LE. 2012. Sustainability transitions in the making: A closer look at actors, strategies and resources. Technological Forecasting and Social Change 79(6): 991-998.

Francis J, van Huis A, Röling N. (Eds). 2016. Innovation Systems: towards effective strategies in support of smallholder farmers. Wageningen: WUR \& CTA.

Fuenfschilling L, Truffer B. 2016. The interplay of institutions, actors and technologies in socio-technical systems - An analysis of transformations in the Australian urban water sector. Technology Forecasting and Social Change 103: 298-312.

Geels FW. 2005. Processes and patterns in transitions and system innovation. Refining the co-evolutionary multi-level perspective. Technology Forecasting and Social Change 72: 681-696.

Geels FW, Schot J. 2007. Typology of sociotechnical transition pathways. Research Policy 36(3): 399-417.

Gibon V, de Greyt W, Kellens M. 2007. Palm oil refining. European J Lipid Sci Technology 109: 315-335.

Hall A, Clark N. 2010. What do complex adaptive systems look like and what are the implications for innovation policy? J Int Dev 22(3): 308-324.

Hekkert MP, Suurs RAA, Negro SO, Kuhlmann S, Smits REHM. 2007. Functions of innovation systems: a new approach for analysing technological change. Technological Forecasting Social Change 74(4): 413-432.

Hermans F, Roep D, Klerkx L. 2016. Scale dynamics of grassroots innovations through parallel pathways of transformative change. Ecological Econ 130: 285-295.

Holtz G, Brugnach M, Pahl-Wostl C. 2008Specifying "regime" - A framework for defining and describing regimes in transition research. Technological Forecasting and Social Change 75: 623-643.
Hounkonnou D, Kossou D, Kuyper TW, Leeuwis C, Nederlof ES, Röling N, et al. 2012. An innovation systems approach to institutional change: Smallholder development in West Africa. Agric Systems 108(5): 74-83.

Jiggins J, Essegbey G, Klerkx L, van Paassen A, Pyburn R, Tossou R. 2016a. The Use of research in and across nine agro-enterprise domains. The experience of the Convergence of Sciences Strengthening Innovation Systems Programme in Benin, Ghana and Mali. In: Francis J, van Huis A, Röling N, eds. Innovation Systems: towards effective strategies in support of smallholder farmers. Wageningen: WUR and CTA.

Jiggins J, Hounkonnou D, Sakyi-Dawson O, Kossou D, Traoré M, Röling N, van Huis A. 2016b. Introduction: Innovation Platforms to support smallholder development - experiences from subsaharan Africa. Cahiers Agricultures 25(6). DOI: 10.1051/cagri/ 2016051.

Kilelu CW, Klerkx L, Leeuwis C. 2013. Unravelling the role of innovation platforms in supporting co-evolution of innovation: contributions and tensions in a smallholder dairy development programme. Agric Systems 118: 65-77.

Klerkx L, Aarts N, Leeuwis C. 2010. Adaptive management in agricultural innovation systems: The interaction between innovation networks and their environment. Agric Systems 103: 390-400.

Klerkx L, van Mierlo B, Leeuwis C. 2012. Evolution of system approaches to agricultural innovation: concepts, analysis and interactions. In: Darnhofer I, Gibbon D, Dedieu B, eds. Farming Systems Research into the 21 st Century: the new dynamic. Berlin: Springer. 457-489.

Klerkx L, Adjei-Nsiah S, Adu Acheampong R, Saidou A, Zannou E, Soumanou L.et al. 2013. Looking at agricultural innovation through an innovation champion lens. An analysis of three cases in West Africa. Outlook Agric 42(3): 185-192.

Leeuwis C. 2000. Re-conceptualising participation for sustainable rural development. Towards a negotiation approach. Dev Change 31(5): 931-959.

MPOC (Malaysian Palm Oil Council). 2009. Ghana's edible oil sector awaits palmoil players. Malaysian Palm Oil Fortune 4: $5-10$.

Nederlof ES, Pyburn R. (Eds). 2012. One finger cannot lift a rock. Facilitating innovation platforms to trigger institutional change in West-Africa. Amsterdam: KIT - Royal Tropical Institute.

Ngwenya H, Hagmann J. 2001. Making innovation systems work in practice: experiences in developing and facilitating innovation platforms. Knowledge Management Dev J 7(1): 109-126.

North DC. 1990. Institutions, Institutional Change and Economic Performance. New York: Cambridge University Press.

Osei-Amponsah C, Visser L, Adjei-Nsiah S, Struik P, Sakyi-Dawson O, Stomph TJ. 2012. Processing practices of small-scale palm oil processors in the Kwaebibirem District Ghana, a diagnostic study. NJAS Wag J Life Sc 60-63: 49-56.

Osei-Amponsah C, Stomph TJ, Visser L, Sakyi-Dawson O, AdjeiNsiah S, Struik P. 2014. Institutional change and the quality of palm oil: an analysis of the artisanal processing sector in Ghana. Int $J$ Agric Sust 12(3): 233-247.

Pacheco DF, York JG, Dean TJ, Sarasvathy SD. 2010. The coevolution of Institutional Entrepreneurship: A Tale of Two Theories. J Management 36(4): 974-1010.

Roep D, Ploeg JD, van der Wiskerke JSC. 2003. Managing technicalinstitutional design processes: some strategic lessons from environmental co-operatives in the Netherlands. NJAS-Wag J Life Sc 51(1-2): 195-217. 
Smink MM, Hekkert MP, Negro SO. 2015. Keeping sustainable innovation on a leash? Exploring incumbents' institutional strategies. Business Strategy Envir 24: 86-101.

van Paassen A, Klerkx L, Adu-Acheampong R, Adjei-Nsiah S, Ouologuem B, Zannou E. 2013. Choice making in facilitation of agricultural innovation platforms in different contexts in West Africa: experiences from Benin, Ghana and Mali. Knowledge Management Dev J 9(3): 79-94. van Paassen, A, Klerkx, L, Adu-Acheampong, R, Adjei-Nsiah, S, Zannou, E. 2014. Agricultural innovation platforms in West Africa: How does strategic institutional entrepreneurship unfold in different value chain contexts? Outlook Agric 43: 193-200.

Wigboldus S, Klerkx L, Leeuwis C, Schut M, Muilerman S, Jochemsen, H. 2016. Systemic perspectives on scaling agricultural innovations. A review. Agron Sust Dev 36: 1-20.

Cite this article as: Adjei-Nsiah S, Klerkx L. 2016. Innovation Platforms and institutional change: the case of small-scale palm oil processing in Ghana. Cah. Agric. 25: 65005. 